\title{
TrkA Expression in the CNS: Evidence for the Existence of Several Novel NGF-Responsive CNS Neurons
}

\author{
David M. Holtzman, ${ }^{1}$ Joshua Kilbridge, ${ }^{1}$ Yiwen Li, ${ }^{1}$ Emmett T. Cunningham, Jr., ${ }^{2}$ Nicholas J. Lenn, ${ }^{7}$ Douglas \\ O. Clary, ${ }^{3,5,6}$ Louis F. Reichardt, ${ }^{3,5,6}$ and William C. Mobley ${ }^{1,4,6}$ \\ Departments of ${ }^{1}$ Neurology, ${ }^{2}$ Ophthalmology, ${ }^{3}$ Physiology, and ${ }^{4}$ Pediatrics, ${ }^{5}$ Howard Hughes Medical Institute, and \\ ${ }^{6}$ Neuroscience Program, University of California at San. Francisco, San Francisco, California 94143 and ${ }^{7}$ Division of \\ Pediatric Neurology, State University of New York, Stony Brook, New York 11794
}

NGF acts as a neurotrophic factor by binding and activating its receptor on certain neuronal populations in the CNS and PNS. TrkA is a receptor for NGF. Recent findings in vitro indicate that this NGF-activated receptor tyrosine kinase transduces the NGF signal. To further define NGF actions in the CNS, we examined trkA expression in the adult rat brain. We found that $\operatorname{trk} A$ mRNA and immunoreactivity (IR) coincided in specific, defined neuronal populations in the forebrain and brainstem. In addition to cholinergic neurons in the basal forebrain and neostriatum, trkA expression was found in noncholinergic neurons in (1) the paraventricular anterior and reuniens thalamic nuclei, (2) the rostral and intermediate subnuclei of the interpeduncular nucleus (IPN), (3) scattered neurons in the ventrolateral and paramedian medulla, (4) the prepositus hypoglossal nucleus, and (5) the area postrema. NGF responsiveness was demonstrated for each of these populations. In contrast to trkA, p75 NGFR was found only in a minority of NGFresponsive populations. Our data provide further evidence that expression of trkA marks NGF-responsive CNS neurons and suggests novel roles for NGF in the brain.

[Key words: NGF, neurotrophin, trk, interpeduncular, paraventricular, prepositus hypoglossal, area postrema, striatum, basal forebrainj

The neurotrophins are structurally related polypeptides that make up one family of neurotrophic factors (Thoenen, 1991). NGF is the best characterized member of this family which includes brain derived neurotrophic factor (BDNF), neurotrophin-3 (NT-3), and NT-4/5 (Thoenen, 1991; Chao, 1992). NGF plays a critical role in the survival and maintenance of dorsal root ganglion and sympathetic neurons in the developing and adult PNS (Johnson and Gorin, 1980; Levi-Montalcini, 1987; Longo et al., 1992). NGF also acts on neostriatal and basal forebrain cholinergic neurons in the developing and mature CNS and may serve as a trophic factor for these cells (for review, see Longo et al., 1992).

Received Mar. 4, 1994; revised May 13, 1994; accepted Aug. 30, 1994.

This work was supported by NIH Grants AG00445 and NS32553 to D.M.H., NS24054 and AG10672 to W.C.M., and NIMH48200 to L.F.R. During this work, D.M.H. was supported as a National Down Syndrome Scholar and D.O.C. was a Helen Hay Whitney fellow.

Correspondence should be addressed to David M. Holtzman, M.D., Washington University School of Medicine, Department of Neurology, Campus Box 8111,660 South Euclid Avenue, St. Lonis, MO 63110

Copyright $@ 1995$ Society for Neuroscience 0270-6474/95/151567-10\$05.00/0
NGF signals by binding to and activating specific cell surface receptors. As is the case for the other neurotrophins, NGF binds to p75 ${ }^{\text {NGFR }}$ (Johnson et al., 1986; Radeke et al., 1987), a transmembrane glycoprotein, and to a receptor tyrosine kinase of the trk gene family. TrkA is the receptor for NGF, trkB for BDNF and NT4/5, and trkC for NT-3 (Klein ct al., 1990; Kaplan et al., 1991; Lamballe et al., 1991; Meakin and Shooter, 1991). NGF binding to trkA results in dimerization and autophosphorylation on tyrosine residues with resultant activation of signaling (Kaplan et al., 1991b; Jing et al., 1992). Studies in cell lines transfected with members of the $t r k$ gene family indicate that activation of a trk transduces neurotrophin signaling (Cordon-Cardo et al., 1991; Loeb et al., 1991; Zhou et al., 1994). Under certain conditions and depending on cellular context, p75 ${ }^{\text {NGFR }}$ appears capable of facilitating trk activation (Verdi et al. 1994). Intcrestingly, p $75^{\text {NGFR }}$ knockout mice have abnormalities of the PNS (Lee et al., 1992), and trigeminal sensory neurons from these animals have an altered dose response to NGF (Davies et al, 1993). While this suggests that $\mathrm{p} 75^{\mathrm{NGFR}}$ modulates neurotrophin signaling in at least some neuronal populations, its exact role remains to be defined. Taken together, these observations indicate that trk expression is key to neurotrophin responsiveness and suggest that localization of trk expression can be used further to define the biological functions of NGF and other neurotrophins. These findings may be relevant to disease states in which the interaction of a neurotrophin with its receptor may be implicated in either pathophysiology or treatment.

While localization of trk expression is an important clue to neurotrophin responsiveness, it is insufficient to prove the case. This is due in part, to the existence of truncated isoforms of both trkB and $t r k C$ that lack a tyrosine kinase domain and to nonsignaling isoforms of trkC (Klein et al., 1990; Tsoulfas et al., 1993; Valenzuela et al., 1993). To date, only two $t r k \Lambda$ isoforms have been discovered and each contains the kinase domain and signals in response to NGF binding (Barker et al., 1993). However, it is conceivable that coexpression of $\operatorname{trkA}$ with truncated isoforms of trkB or trkC could diminish signaling through trkA or that other factors could negatively modulate signaling. These considerations emphasize that while localization of $t r k$ mRNAs and proteins can help to suggest neurotrophin targets, it is essential to demonstrate a neurotrophin response in the neurons thus identified.

Many studies have now shown that basal forebrain and neostriatal cholinergic neurons are NGF responsive (Gnahn et al., 1983; Hefti et al., 1985; Mobley et al., 1985; Hagg et al., 1989; 
Higgins et al., 1989). It has been shown that trkA is expressed in these neurons (Holtzman et al., 1992b; Steininger et al., 1993). Moreover, in vitro and in vivo studies have shown that NGF rapidly induces phosphorylation of trkA in these cells (Knusel et al., 1992; Knusel et al., 1994). Widespread localization of NGF mRNA and protein in the CNS suggested that there existed other NGF-responsive populations (Large et al., 1986; Whittemore et al., 1986). Recently, several other CNS neuronal populations have been reported to express trkA mRNA (Merlio et al., 1992; Venero and Hefti, 1993). However, it is uncertain as to whether these, or perhaps other CNS neurons express trkA protein and respond to NGF. Herein, we document trkA expression in nine CNS neuronal populations in seven brain regions. Significantly, we show that each population is able to respond to NGF. These results suggest novel trophic roles for NGF in the adult mammalian brain.

\section{Materials and Methods}

Animal preparation and NGF injection. Female Sprague-Dawley rats (3-6 month old) were used for all studies. For trkA expression studies, eight animals were used for in situ hybridization histochemistry (ISHH) and eight for immunocytochemistry. Rats were deeply anesthetized (Holtzman et al., 1992a) and perfused transcardially with $60 \mathrm{ml}$ of PBS $\left(\mathrm{pH} 7.4,4^{\circ} \mathrm{C}\right.$ ) followed by $200 \mathrm{ml}$ of $4 \%(\mathrm{wt} / \mathrm{vol})$ paraformaldehyde in $0.1 \mathrm{M}$ sodium phosphate $\left(\mathrm{pH} 7.4,4^{\circ} \mathrm{C}\right)$. Brains were removed, postfixed overnight in the same fixative, and then dehydrated in $20 \% \mathrm{wt} / \mathrm{vol} \mathrm{su-}$ crose in $0.1 \mathrm{M}$ sodium phosphate $\left(\mathrm{pH} 7.4,4^{\circ} \mathrm{C}\right)$. They were then frozen in powdered dry ice and stored at $-70^{\circ} \mathrm{C}$. For NGF studies, animals received a $14 \mathrm{~d}$ infusion of mouse NGF (Mobley et al., 1986) dissolved in vehicle (artificial CSF, $N=3$ ) or the vehicle alone $(N=3)$ into the right lateral ventricle (Holtzman et al., 1993). Composition of artificial CSF was as follows: $150 \mathrm{~mm} \mathrm{NaCl}, 3.0 \mathrm{mM} \mathrm{KCl}, 1.4 \mathrm{mM} \mathrm{CaCl}_{2}, 0.8$ $\mathrm{mM} \mathrm{MgCl}_{2}, 1 \mathrm{~mm} \mathrm{Na} \mathrm{HPO}_{4}-\mathrm{NaH}_{2} \mathrm{PO}_{4}$. Surgical procedures were performed exactly as described (Holtzman, et al., 1993) with the following modifications: (1) Alzet model 2002 miniosmotic pumps (Alza Corp., Palo Alto, CA) were used; (2) cannula placement was $0.2 \mathrm{~mm}$ anterior to bregma, $1.1 \mathrm{~mm}$ lateral to the midline, and $5.0 \mathrm{~mm}$ ventral to the skull surface; and (3) flow rate was $0.5 \mu \mathrm{l} / \mathrm{hr}(1.25 \mu \mathrm{g} \mathrm{NGF} / \mathrm{hr}=30$ $\mu \mathrm{g}$ NGF/24 hr).

In situ hybridization histochemistry (ISHH) and immunocytochemistry. Thirty micrometer coronal sections (for ISHH) or $40 \mu \mathrm{m}$ coronal sections (for immunocytochemistry) were cut on a freezing sliding microtome and collected in $0.1 \mathrm{M}$ Tris-buffered saline (TBS, pH 7.6, $4^{\circ} \mathrm{C}$ ). Serial sections were examined from the olfactory bulb rostrally through the entire medulla caudally. For ISHH, sections were mounted on Superfrost plus slides (Fisher Scientific, Springfield, NJ) and allowed to dry overnight. They were then stored at $-70^{\circ} \mathrm{C}$ prior to ISHH. ISHH was carried out using RNA probes under stringent conditions exactly as described (Cunningham and De Souza, 1993). Probes were labeled with either $\mathrm{S}^{35}$-UTP $(1225 \mathrm{Ci} / \mathrm{mmol})$ or $\mathrm{P}^{33}$-UTP $(1700 \mathrm{Ci} / \mathrm{mmol})(\mathrm{Du}$ Pont, New England Nuclear, Boston, MA). TrkA sense and antisense riboprobes were generated from pDM97 (gift of L. Parada), a plasmid containing a 434 bp mouse trkA cDNA cloned into pGEM-7Zf (Promega, Madison, WI) (Holtzman et al., 1992b). The insert corresponds to a portion of the extracellular domain of mouse trkA and is specific for $\operatorname{trkA}$.

Immunocytochemistry for trkA, ChAT, and p $75^{\text {NGFR }}$ were performed as described (Holtzman et al., 1992a,b). In these experiments, omission of the primary antibody resulted in no staining in any brain region. Tise antibody to trkA (RTA, used at 1/4000) is specific for trkA. It was raised in rabbits to the baculovirus expressed extracellular domain of rat trkA. On antigen blots, it recognizes trkA but does not recognize either trkB or trkC (Clary et al., 1994). NADPH-d histochemistry was performed as described (Ferriero et al., 1988). In colocalization studies, NADPH-d staining was performed on sections which were first immunostained for trkA.

Trk phosphorylation assay. Sixteen adult female Sprague-Dawley rats were anesthetized (Holtzman et al., 1992a) and brains were removed and placed in cold PBS ( $\left.\mathrm{pH} 7.4,4^{\circ} \mathrm{C}\right)$. The septal region was dissected as described (Johnston et al., 1987). A dissecting microscope was used to visualize the midline ventral mesencephalon (containing the IPN). Two fine tweezers were used to remove the overlying meninges and blood vessels and then a square piece of tissue $(\sim 2 \times 2 \mathrm{~mm})$ lying within the interpeduncular fossa was removed. Tissue from each region was then cut into pieces $\sim 0.5 \times 0.5 \mathrm{~mm}$ using microdissecting scissors. The tissue from the septal region or midline ventral mesencephalon from 16 animals was then separated into four groups $(N=4$ per group) and triturated $10 \times$ with a glass pipette tip $(\sim 500 \mu \mathrm{m})$ and then $10 \times$ with a fire-polished glass pipette tip $(\sim 150 \mu \mathrm{m})$. This procedure produced individual cells and cell clusters. Tissue from each brain region was then collected into a $1.5 \mathrm{ml}$ Eppendorf tube and incubated with NGF (100 ng/ml) in vehicle (Hanks BSS, pH 7.4) or in vehicle alone at $37^{\circ} \mathrm{C}$ for $5 \mathrm{~min}$. Immunoprecipitation and antigen blotting were performed as described previously (Kaplan et al., 1991b; Zhou et al., 1994). Tissue was lysed in lysis buffer ( $20 \mathrm{~mm}$ Tris $\mathrm{HCl}$ $\mathrm{pH} 8.0 ; 150 \mathrm{mM} \mathrm{NaCl} ; 1 \% \mathrm{NP} 40 ; 10 \%$ glycerol; 1 mM sodium orthovanadate; $1 \mathrm{~mm}$ PMSF; $10 \mathrm{mg} / \mathrm{ml}$ benzamidine; $1 \mathrm{mg} / \mathrm{ml}$ o-phenanthroline; $0.1 \mathrm{mg} / \mathrm{ml}$ each pepstatin, chymostatin, leupeptin, and aprotinin). Immunoprecipitation was performed with an anti-pan-trk antibody (1088) overnight at $4^{\circ} \mathrm{C}$ (Zhou et al., 1994). 1088 binds to all full-length trks. Immunoprecipitates were collected using protein A/Sepharose beads (Pierce, Rockford, IL) and were subjected to 7.5\% SDS-PAGE, prior to transfer to nitrocellulose and immunoblotting using an antibody to phosphotyrosine 4G10 (UBI, Lake Placid, NY).

Assessment of trkA-IR neuronal profiles. Measurement of the crosssectional area of trkA-IR profiles in different brain regions was performed with the MCID image analysis system (Imaging Research, Inc., St. Catherines, Ontario) linked to a Leitz Aristoplan microscope (Leica, Inc., Foster City, CA) as described (Holtzman et al., 1993). Cells were visualized utilizing a $40 \times$ objective, and the area of every trkA-IR neuronal profile with a nucleus was assessed. Cell size assessment included measurements in the medial septal nucleus, the neostriatum, the paraventricular anterior nucleus of the thalamus, the rostral subnucleus of the IPN, the prepositus hypoglossal nucleus, the area postrema, and the paragigantocellular reticular region in the medulla. For each animal, one to three coronal sections in each brain region were examined. Every trkA-IR neuron in the medial septal nucleus were measured in one section ( $0.20 \mathrm{~mm}$ anterior to bregma) if it was superior to a line between the anterior commissures and within $0.75 \mathrm{~mm}$ of the midline. All trkAIR neurons from both sides of the neostriatum from the same section were also examined. TrkA-IR neurons in the paraventricular nucleus of the thalamus were measured in thrce adjacent sections $1 \mathrm{~mm}$ posterior to bregma. All IR-cells were within $0.5 \mathrm{~mm}$ of the midline. For the rostral subnucleus of the IPN, three adjacent sections at the level shown in Figure $3 A$ (5.8 $\mathrm{mm}$ caudal to bregma) were assessed. TrkA-IR neurons in the prepositus hypoglossal nucleus from three adjacent sections $12.0 \mathrm{~mm}$ caudal to bregma were measured. For the area postrema and the paragigantocellular reticular nucleus, trkA-IR neurons from three adjacent sections $12.8 \mathrm{~mm}$ caudal to bregma were measured. For the paragigantocellular reticular nucleus, all trkA-IR neurons lateral to the inferior olivary complex and not more than $1.2 \mathrm{~mm}$ dorsal to the ventral surface of the medulla were measured.

\section{Results}

TrkA is localized to several neuronal populations

In situ hybridization (ISHH) and immunocytochemistry were used to define cells containing trkA mRNA and protein in the CNS. Previous studies documented the restricted distribution of trkA expression in the CNS; they showed that essentially all cholinergic neurons in the basal forebrain and neostriatum contain trkA mRNA (Holtzman et al., 1992b) and are immunoreactive (IR) for trkA protein (Steininger et al., 1993). Utilizing a trkA-specific riboprobe and a trkA-specific antibody (RTA), trk A expression was readily detected in neurons in the basal forebrain (Fig. 1A-C) and neostriatum (Fig. 1D-F). All trkAIR cell bodies in the these regions conformed in their distribution and size to cholinergic neurons. TrkA expressing basal forebrain cholinergic neurons are known to project widely to hippocampus and neocortex. TrkA-IR fibers were found in these regions and are likely to reflect the presence of trkA on the surface of axons originating in the basal forebrain. TrkA expressing striatal cholinergic neurons are interneurons whose processes extend 

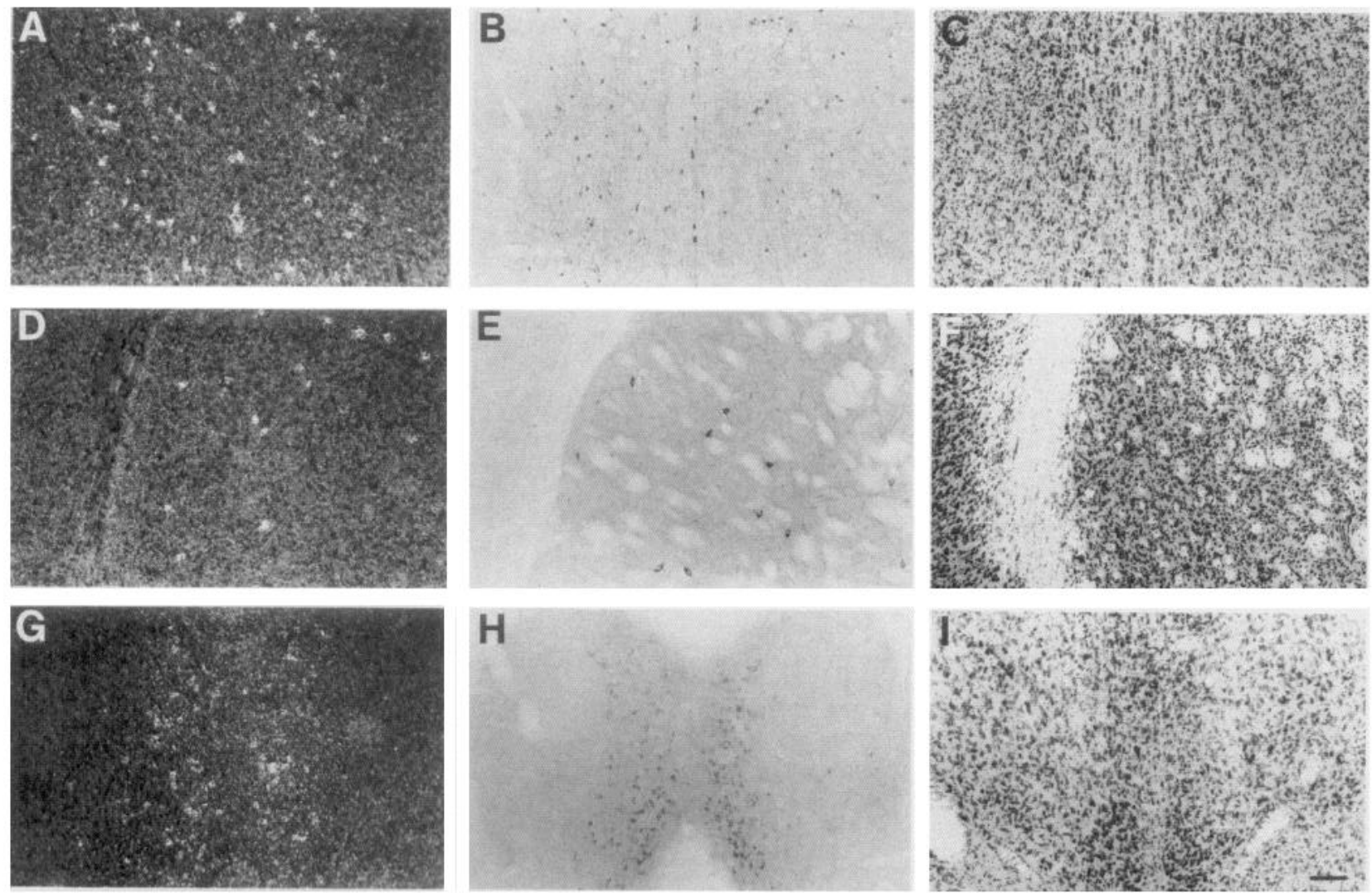

Figure 1. TrkA mRNA and immunoreactivity (IR) in the adult rat forebrain. $A, D$, and $G$ are dark-field photomicrographs of sections hybridized with a $\operatorname{trk} A$ antisense riboprobe; $B, E$, and $H$ are bright-field photomicrographs demonstrating trkA-IR; and $C, F$, and $I$ are bright-field photomicrographs of cresyl violet stained sections. $A-C$ are adjacent coronal sections through the septum $0.20 \mathrm{~mm}$ anterior to bregma in the midline. TrkA containing neurons in the medial septal nucleus are in the same distribution as that seen for ChAT containing neurons (Holtzman et al., 1992b). $D-F$ are adjacent coronal sections $0.20 \mathrm{~mm}$ anterior to bregma (centered $4 \mathrm{~mm}$ lateral to the midline) demonstrating trkA expression in large cholinergic interneurons in the striatum. $G-I$ are coronal sections $1 \mathrm{~mm}$ posterior to bregma. In these sections, trkA expression is seen in small neurons in the paraventricular thalamic nucleus, anterior. These sections are at the same level as plates 17 and 22 of a rat brain atlas (Paxinos and Watson, 1986). All panels are at the same magnification. Scale bar, $120 \mu \mathrm{m}$.

throughout the striatum. Consistent with this pattern was the diffuse trkA-IR found throughout the striatal neuropil (Fig. 1E).

Localization studies revealed several additional populations in the CNS that contained both trkA mRNA and protein. In the diencephalon, populations adjacent to the midline in the anterior paraventricular and reuniens thalamic nuclei expressed trkA (Fig. $1 G-I$ ). In the brainstem, several specific neuronal populations in the midbrain, pons, and medulla also expressed trkA. In the ventral midbrain, trkA mRNA and IR were present in subnuclei of the interpeduncular nucleus (see next section). In the pons and medulla, trkA mRNA and IR were seen in large neurons in the prepositus hypoglossal nucleus (Fig. $2 A-C$ ) and in small neurons in the area postrema (Fig. $2 D-F$ ). In the area postrema, cells along the rim consistently appeared to contain more trkA mRNA than cells located in the core; however, trkA immunostaining revealed trkA-IR neurons throughout the nucleus. TrkA expression was also seen in scattered large neurons in the ventral and paramedian medulla (Fig. $2 G-I$ ). Most of these neurons were located between the inferior olivary complex and the lateral reticular nucleus, an ill-defined region referred to as the gigantocellular and paragigantocellular reticular nuclei (Paxinos and Watson, 1986). A few trkA-IR neurons were also seen within the boundaries of the lateral reticular nucleus (data not shown), although these were similar in size and shape to IR soma in the contiguous reticular formation. Two brainstem nu- clei displayed evidence of trkA-IR cell bodies but by ISHH, showed no evidence of synthesizing trkA mRNA: the dorsal nucleus of the lateral lemniscus and the ventral cochlear nucleus. There was no evidence of trkA expressing cell bodies in the cerebellum.

\section{TrkA was expressed in the interpeduncular nucleus}

The interpeduncular nucleus (IPN) is located in the ventral midline of the midbrain in all mammals. Because of anatomical and neurochemical inhomogeneity, the nucleus has been divided into several subnuclei (Fig. 3) (Lenn and Hamill, 1984). TrkA mRNA and IR were localized to neurons with cell bodies exclusively within the rostral and intermediate subnuclei (Figs. $4 A, B ; 5)$. Together these two subnuclei comprise $55 \%$ of the volume of the IPN. The IPN contains the largest concentration of ACh (Kasa, 1986) and ChAT activity of any brain region studied (Palkovits et al., 1974). ACh in the IPN is present in cholinergic axons and nerve terminals. The cholinergic innervation of the IPN predominantly arises from the thalamic medial habenular nuclei and is conveyed to the subnuclei of the IPN in the fasciculus retroflexus, a prominent fiber bundle (Lenn et al., 1985). No neurons in the habenular complex expressed trkA (data not shown). While there are dense cholinergic terminals in the IPN, there were no cholinergic cell bodies intrinsic to this nucleus (Fig. 4E) (Lenn et al., 1985). TrkA-IR neurons in the 

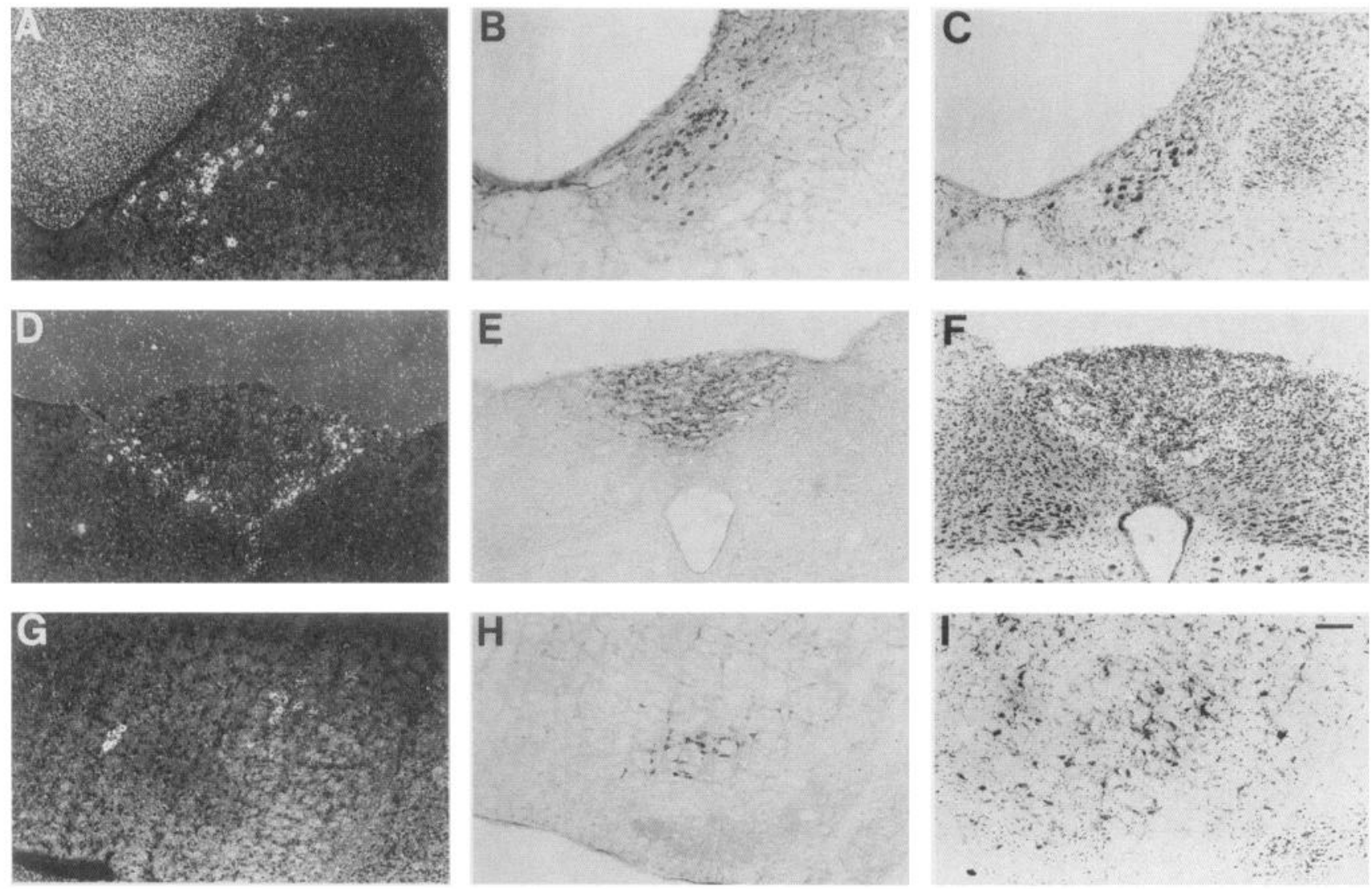

Figure 2. TrkA mRNA and immunoreactivity (IR) in the adult rat brainstem. $A, D$, and $G$ are dark-field photomicrographs of sections hybridized with a trkA antisense riboprobe; $B, E$, and $H$ are bright-field photomicrographs demonstrating trkA-IR; and $C, F$, and $I$ are bright-field photomicrographs of cresyl violet stained sections. $A-C$ are adjacent coronal sections through the dorsal medulla just lateral to the midline $(\sim 12.0 \mathrm{~mm}$ caudal to bregma). Large trkA expressing neurons are seen in the prepositus hypoglossal nucleus. $D-F$ are adjacent coronal sections containing the medial portions of the dorsal medulla $(\sim 13.5 \mathrm{~mm}$ caudal to bregma). Small trkA expressing neurons are seen scattered throughout the area postrema. Although there appears to be more trkA mRNA in neurons around the rim of the area postrema, trkA-IR is present in neurons in both the rim and the core. $G-I$ are adjacent coronal sections through the ventrolateral medulla centered $1.5 \mathrm{~mm}$ to the right of the midline $(\sim 12.8 \mathrm{~mm}$ caudal to bregma). TrkA mRNA and IR are present in large neurons just lateral to the inferior olivary complex. These neurons are in regions referred to as the paragigantocellular and gigantocellular reticular nuclei. The sections in this figure are at the same level as Figures $66(A-C), 69(G-I)$, and 72 $(D-F)$ in the rat brain atlas of Paxinos and Watson (1986). All panels are at the same magnification. Scale bar, $120 \mu \mathrm{m}$.

IPN were small to medium sized (Fig. 6A, Table 1). Prior studies suggest that these cells are likely to be cholinoceptive (Lenn et al., 1985). p75 ${ }^{\text {NGFR }}$-IR was not detected in trkA-expressing IPN neurons (Fig. 4D). Nitric oxide synthase containing neurons, which are NADPH-diaphorase positive, and trkA-IR neurons have overlapping areas of distribution in both the rostral and intermediate subnuclei. However, trkA-IR and NADPH-d activity were not obviously colocalized in double stained sections in the IPN (data not shown).

\section{NGF induced trkA activation}

We asked whether trkA expression in IPN neurons was sufficient to confer NGF-signaling in these cells. NGF receptor activation induces autophosphorylation of trkA on tyrosine, a property that has been demonstrated both in vivo and in vitro (Kaplan et al., 1991, 1991b; Knusel et al., 1994). To determine whether IPN neurons would respond to NGF, dissociated cells from the septal region (containing basal forebrain cholinergic neurons) or the medial portion of the ventral midbrain (containing the IPN) were exposed to NGF, or the vehicle control for $5 \mathrm{~min}$ at $37^{\circ} \mathrm{C}$. Cells were then lysed and trk proteins were immunoprecipitated with an anti-pan-trk antibody and analyzed by SDS-PAGE. For immunoblotting, we used an antibody to phosphotyrosine. Since
NGF interacts specifically with trkA but not with trkB or trkC, any increase in phosphotyrosine on trk proteins due to NGF treatment should represent NGF-induced tyrosine phosphorylation on trkA. NGF treatment induced tyrosine phosphorylation of a 125 kDa protein in both septal and IPN dissociates (Fig. 7). This band appears to correspond to trkA because it was cross-reactive with RTA on antigen blots (data not shown). Thus, probably due to differences in glycosylation, the molecular weight of trkA in the CNS appears slightly less than that seen in PC12 cells ( $140 \mathrm{kDa})$. Interestingly, on a per milligram protein basis, the amount of trkA-associated tyrosine phosphate as a result of NGF treatment was greater in the IPN than in the septum (Fig. 7).

\section{$N G F$ acted on all trkA expressing CNS neuronal populations}

Neuronal hypertrophy was among the first actions described for NGF (Levi-Montalcini, 1987; Longo et al., 1992) and has been seen in every NGF-responsive population examined to date. To determine whether NGF would activate signaling in trkA expressing CNS neurons, we asked whether NGF would induce hypertrophy in these cells. NGF was infused into the lateral ventricle of adult rats for 2 weeks. Artificial CSF served as the vehicle control. Following NGF administration, there was no discernable increase in the staining density of trkA-IR cell pro- 

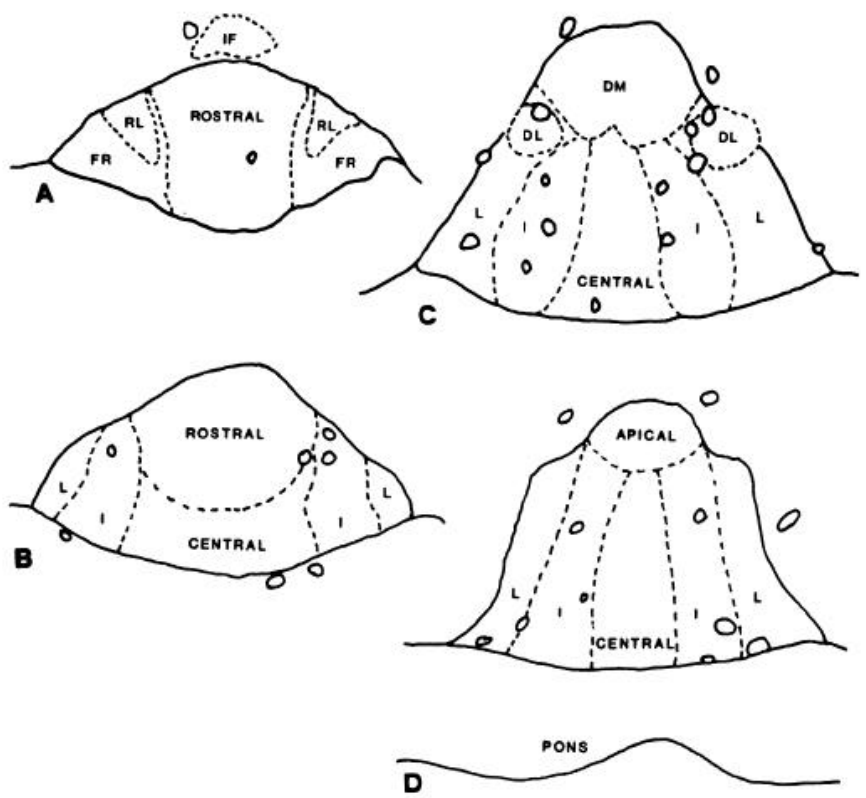

Figure 3. Camera lucida drawing of four levels of the IPN in the coronal plane, from $A$, most rostral to $D$, most caudal. $I F$, Intrafascicular nucleus, not part of IPN; $F R$, fasciculus retroflexus; $R L$, rostrolateral subnucleus; $D L$, dorsolateral subnucleus; $D M$, dorsomedial subnucleus; $L$, lateral subnucleus; $I$, intermediate subnucleus. Modified from Hamill and Lenn (1984), Lenn and Hamill (1984), and Groenewegen et al. (1986). files in any of the populations assessed. Cross-sectional area of trkA-IR profiles containing nuclei was measured in all neuronal populations containing trkA mRNA and IR. The mean crosssectional area was uniformly increased in NGF-treated subjects. The increase ranged from $15-28 \%$ (Table 1). In all cases, the increases were statistically significant (Table 1). The degree of hypertrophy in the newly defined trkA-IR neuronal profiles was equivalent to that seen for profiles of basal forebrain and neostriatal cholinergic neurons. Thus, robust NGF actions were recorded in all trkA expressing CNS neuronal populations. Evidence that NGF affected most if not all trkA-IR neurons within each population comes from analysis of neuronal profile distributions. The size distribution of trkA-IR profiles were normal (not skewed) in each forebrain and brainstem region examined in both NGF- and vehicle-treated subjects. In NGF-treated brains, the entire distribution of sizes were shifted to the right. In striatal trkA-IR neurons, we also assessed the mean crosssectional area of nuclei. NGF increased this measure by $19 \%$ $\left(\mathrm{NGF}=56.8 \mu \mathrm{m}^{2} \pm 1.5, n=275, N=3 ; \mathrm{VEH}=47.8 \mu \mathrm{m}^{2}\right.$ $\pm 1.4, n=258 ; p<0.0001)$.

To establish that the effect of NGF was specific for trkAexpressing neurons, we examined neostriatal neurons which stain for NADPH-d. These cells do not contain trkA-IR. Cell size was measured in NGF and vehicle treated animals. NGF infusion did not affect the size of these neurons (NGF $=120.5$ $\mu \mathrm{m}^{2} \pm 2.5, n=351, N=3 ; \mathrm{VEH}=120.4 \pm 2.6, n=340$, $N=3 ; p=0.95)$.
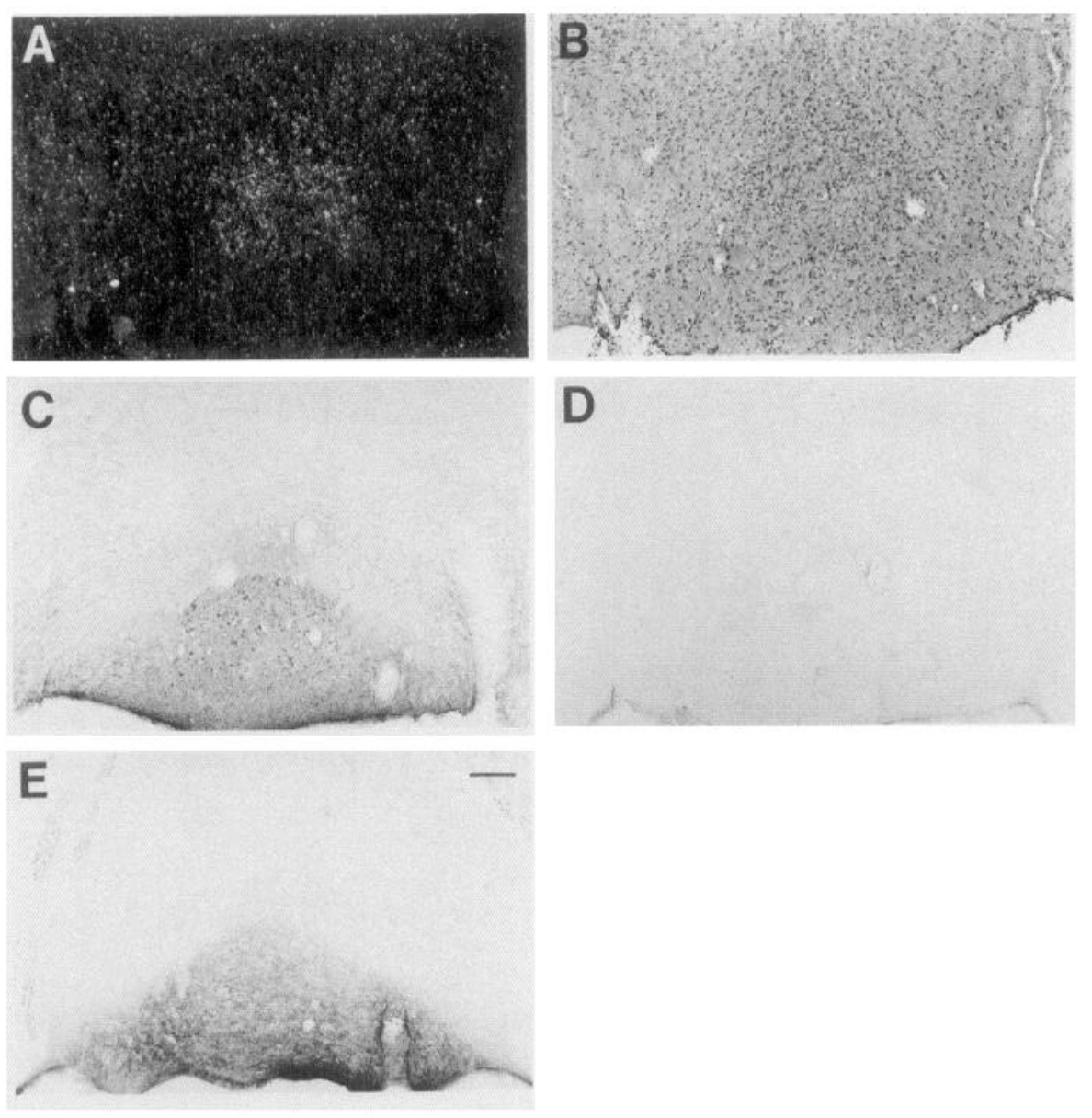

Figure 4. Localization of NGF-receptors and ChAT in the adult rat IPN. Five panels corresponding to Figure $3 A$. $A$, ISHH reveals trkA mRNA expression in the rostral subnucleus (dark-field photomicrograph). $B$, Same section stained with $H$ and $E$ (brightfield photomicrograph). $C$, Immunostaining reveals that trkA-IR in small neurons in the rostral subnucleus. In $D$, immunostaining for $\mathrm{p} 75^{\mathrm{NGFR}}$ gives no evidence for either cell body or fiber staining in this region. $E$, Immunostaining for ChAT shows abundant ChATIR fibers; these originate predominantly in the medial habenula. Scale bar, $120 \mu \mathrm{m}$. All panels are the same magnification. 

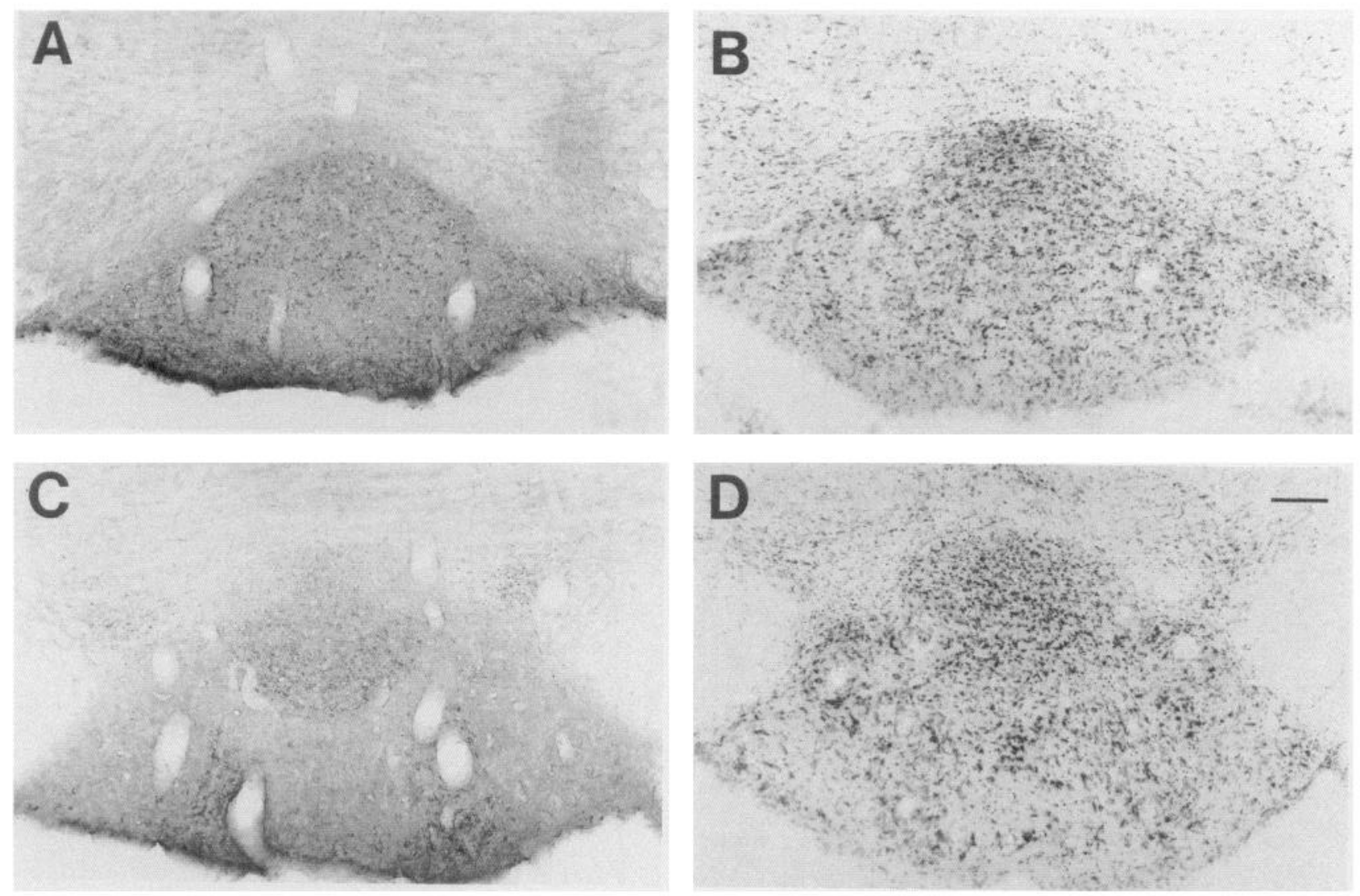

Figure 5. TrkA immunostaining in the IPN. $A$ and $B$, At the level of the IPN corresponding to Figure $3 A$. $A$, trkA-IR is seen in a subpopulation of small neurons in the rostral subnucleus. $B$, Adjacent section stained with cresyl violet. $C$ and $D$, At the level of the IPN just caudal to Figure $3 B$. $C$, trkA-IR is seen in a subpopulation of medium sized neurons in the intermediate subnuclei (bilateral) and the single rostral subnucleus (midline). D, Adjacent section stained with cresyl violet. Scale bar, $120 \mu \mathrm{m}$. All panels are the same magnification.

\section{Discussion}

The major findings in this study are (1) the discovery of novel trkA expressing NGF-responsive neurons in five brain regions and (2) that NGF responsiveness correlates withtrkA expression in the CNS. In addition to basal forebrain and neostriatal cholinergic neurons, NGF-responsive neurons were found in the (1) paraventricular anterior and reuniens thalamic nuclei, (2) rostral and intermediate subnuclei of the interpeduncular nucleus, (3) prepositus hypoglossal nucleus, (4) area postrema, and (5) ventrolateral medulla. The data confirm that trkA plays a critical role in NGF signaling and raise the possibility that NGF acts as a trophic factor for the newly defined neuronal populations, contributing to their development and normal mature function.

The use of a $\operatorname{trk} A$-specific riboprobe and antibody allowed us to detect potential NGF-responsive neuronal populations. Our studies give data which both complement and contrast with findings in earlier studies. There is agreement that $\operatorname{trk} A$ mRNA and protein (Holtzman et al., 1992b; Steininger et al., 1993) as well as specific NGF binding (Richardson et al., 1986; Raivich and Kretuzber, 1987) are found in cholinergic neurons in the basal forebrain and neostriatum; the response of these neurons to NGF is well studied. Merlio et al. found $\operatorname{trkA}$ mRNA in neurons within the interpeduncular nucleus, the raphe obscurus, the dorsal raphe, and the gigantocellular and paragigantocellular nuclei (Merlio et al., 1992). Although we did observe trkA expression in scattered neurons in the medullary paramedian reticular formation in the vicinity of known serotonergic neurons, we de- tected no trkA mRNA and protein in the raphe obscurus and dorsal raphe nuclei. As was true in our studies, Venero and Hefti found trkA mRNA within neurons of the paraventricular anterior and reuniens thalamic nuclei of the thalamus (Venero and Hefti, 1993). Radiolabeled NGF was reported to bind to neuronal cell bodies in the ventral cochlear nucleus, dorsal nucleus of the lateral lemniscus, the prepositus hypoglossal nucleus, and the medullary reticular formation (Richardson et al., 1986; Raivich and Kretuzber, 1987). While we did not find evidence for trkA mRNA in the ventral cochlear nucleus or the dorsal nucleus of the lateral lemniscus, our immunostaining results give evidence that trkA could have mediated NGF binding in these nuclei. Why these regions contained detectable trkA-IR without trkA mRNA is unclear. Conceivably, these cells express trkA mRNA at lower levels than other trkA expressing neurons. If so trkAIR using the RTA antibody may be a more sensitive method for detecting trkA expression. Further studies will be required to address this point and the response of these neurons to NGF. Altar et al. (1991) found NGF binding in the paraventricular nucleus of the thalamus as well as in the "rostral and lateral subnuclei of the IPN." Binding in the IPN was attributed to receptors on cholinergic fibers. Our findings show that this binding was probably due in large part to trkA expressed on neuronal cell bodies in this region. The relationship between the results of this and earlier studies localizing trkA expression and NGF binding is now more clear; every CNS neuronal group in which trkA mRNA and protein have been detected responds to NGF. 

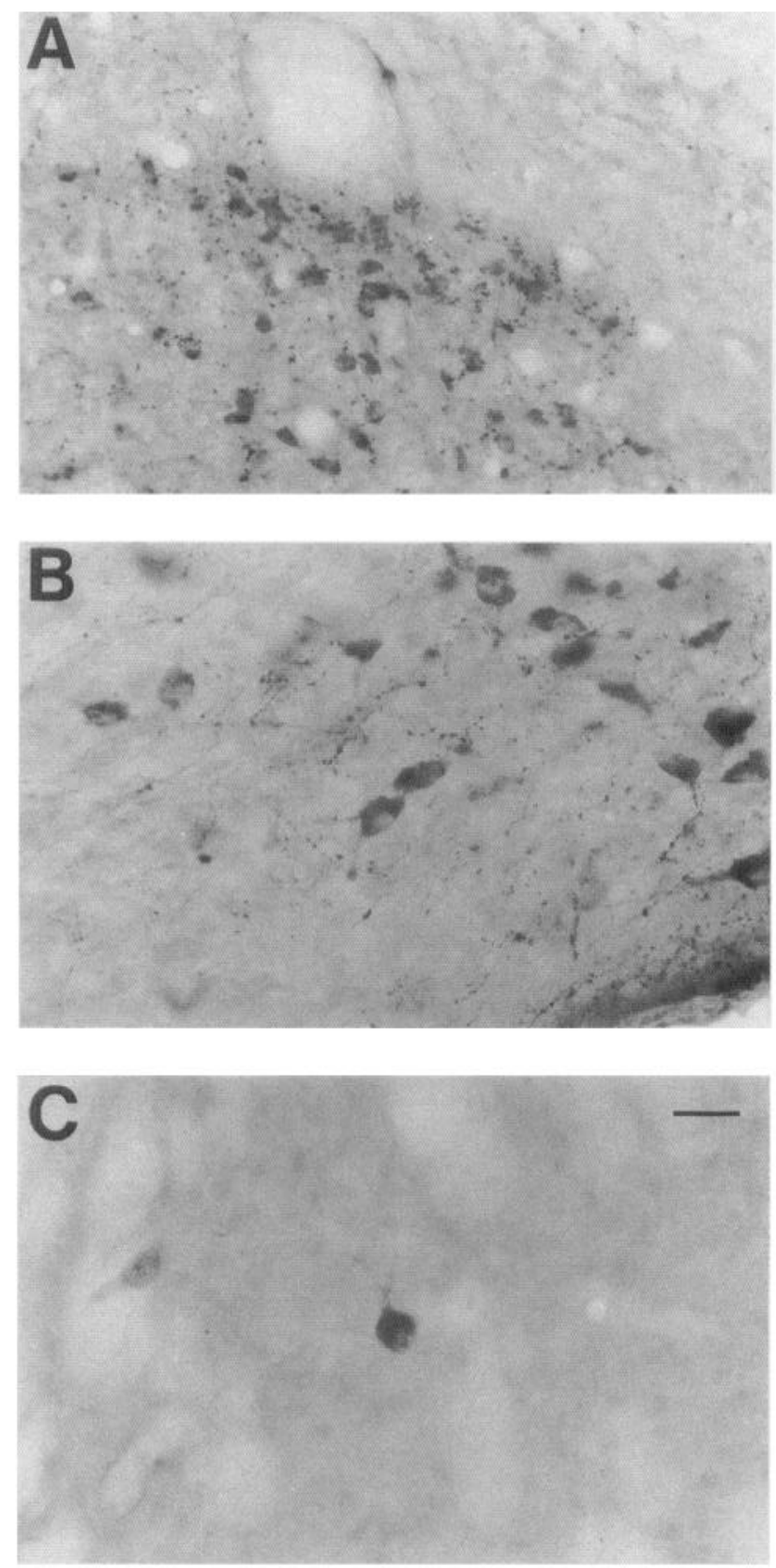

Figure 6. TrkA immunostaining in the IPN, basal forebrain, and striatum. $A$, trkA-IR neurons in the rostral IPN. There is cell body staining of small neurons as well as fiber staining (seen as punctate swellings). These neurons are smaller (Table 1) than the trkA-IR cholinergic neurons in the vertical limb of the diagonal band $(B)$ or the striatum $(C)$. Abundant trkA-IR fibers are seen in the vertical limb of the diagonal band $(B)$. Scale bar, $30 \mu \mathrm{m}$. $A-C$ are at the same magnification.

Both populations of CNS neurons previously identified as NGF-responsive are cholinergic. It is noteworthy that not one of the other trkA expressing populations described herein are known to be cholinergic. The neurotransmitter phenotype of the newly defined trkA expressing neurons is unknown. Indeed in their localization, morphology, and probable connectivity, trkA expressing neurons appear to be quite diverse.

Autophosphorylation of trk on tyrosine is a manifestation of trk kinase activation by neurotrophins. We showed that NGF can rapidly induce the phosphorylation of trk on tyrosine in tissue
Table 1. NGF increases the mean cross-sectional area of trkA-IR neuronal profiles $\left(\mu \mathbf{m}^{2}\right)$

\begin{tabular}{|c|c|c|c|}
\hline & NGF & VEH & $\%$ Change \\
\hline Medial septal nucleus & $\begin{array}{l}161.2 \pm 3.7 * \\
(n=156)\end{array}$ & $\begin{array}{l}132.2 \pm 2.7 \\
(n=181)\end{array}$ & 22 \\
\hline Striatum & $\begin{array}{l}225.2 \pm 3.6^{*} \\
(n=278)\end{array}$ & $\begin{array}{l}193.6 \pm 2.9 \\
(n=259)\end{array}$ & 16 \\
\hline $\begin{array}{l}\text { Paraventricular nucleus } \\
\text { (anterior) }\end{array}$ & $\begin{array}{l}148.1 \pm 1.9 * \\
(n=252)\end{array}$ & $\begin{array}{l}125.0 \pm 2.1 \\
(n=220)\end{array}$ & 18 \\
\hline $\begin{array}{l}\text { interpeduncular nucleus } \\
\text { (rostral subnucleus) }\end{array}$ & $\begin{array}{l}99.0 \pm 1.2^{*} \\
(n=198)\end{array}$ & $\begin{array}{l}80.0 \pm 0.9 \\
(n=180)\end{array}$ & 24 \\
\hline $\begin{array}{l}\text { Prepositus hypoglossal } \\
\text { nucleus }\end{array}$ & $\begin{array}{l}354.8 \pm 6.0^{*} \\
(n=233)\end{array}$ & $\begin{array}{l}276.9 \pm 5.8 \\
(n=238)\end{array}$ & 28 \\
\hline $\begin{array}{l}\text { Paragigantocellular } \\
\text { region }\end{array}$ & $\begin{array}{l}288.9 \pm 5.8^{*} \\
(n=198)\end{array}$ & $\begin{array}{l}251.9 \pm 5.4 \\
(n=193)\end{array}$ & 15 \\
\hline Area postrema & $\begin{array}{l}100.0 \pm 1.4^{*} \\
(n=188)\end{array}$ & $\begin{array}{l}85.4 \pm 1.2 \\
(n=210)\end{array}$ & 17 \\
\hline
\end{tabular}

Data present mean cross-sectional area of trkA-IR profiles containing nuclei in various brain regions after the 2 week infusion of NGF or vehicle. In all brain regions assessed, NGF caused significant hypertrophy $(15-28 \%)$ of trkA-IR neuronal profiles. Student's $t$ test was utilized for statistical comparisons.

${ }^{*} p<0.0001$ versus vehicle only, Student's $t$ test.

from both the adult rat septum and ventral midline of the midbrain. Expression of trkA was thus correlated with NGF-signaling. We showed that NGF increased the mean cross-sectional area of trkA-IR neuronal profiles in all trkA-expressing CNS neuronal populations by shifting the normal size distribution of these profiles to the right. While unbiased stereological techniques would be required to document absolute changes in cellular surface area and volume due to NGF, such techniques were not necessary to document a treatment effect. This is because the small amount of bias introduced with our methods would be virtually identical for both NGF- and vehicle-treated subjects. An increase in mean cross-sectional area of trkA-IR profiles in all trkA-expressing CNS populations in response to NGF administration strongly suggests that trkA expression not only provides for NGF-signaling but also for a meaningful biological response. Such a response is not uniformly seen in the case of cells expressing $t r k B$ and $t r k C$. Kaplan and coworkers have recently shown that mature CNS neurons show little evidence of BDNF, NT-3, or NT-4/5 signaling in spite of the expression of trkB and $t r k C$ (Knusel et al., 1994). In part, this may be due to expression of truncated forms of trkB that lack the tyrosine kinase domain (Klein et al., 1990; Middlemas et al., 1991) and both truncated and alternative forms of $\operatorname{trkC}$ that do not signal (Tsoulfas et al., 1993; Valenzuela et al., 1993). Certainly for $t r k B$ and $t r k C$, evidence of gene expression is insufficient to prove neurotrophin responsiveness. Even in the case of $\operatorname{trk} A$, we would urge caution and suggest that responses to NGF be demonstrated and not simply inferred from data for expression of trkA.

While the localization of trkA mRNA, trkA-IR, and NGF responsiveness were always coincident, only in the basal forebrain, prepositus hypoglossal nucleus, and area postrema was there was a correlation with the expression of $\mathrm{p} 75^{\mathrm{NGFR}}$ (Koh et al., 1989). While it appears under certain conditions that $\mathrm{p} 75^{\mathrm{NGFR}}$ can modulate NGF-signaling (Lee et al., 1992; Davies et al., 1993; Verdi et al., 1994), our results suggest that its expression is not required for NGF responsiveness in the CNS. One issue that is raised is whether the affinity of NGF receptors is adequate to transduce a physiologic NGF signal in neurons that do not 


\section{0 kD -

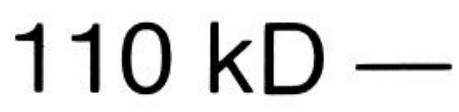

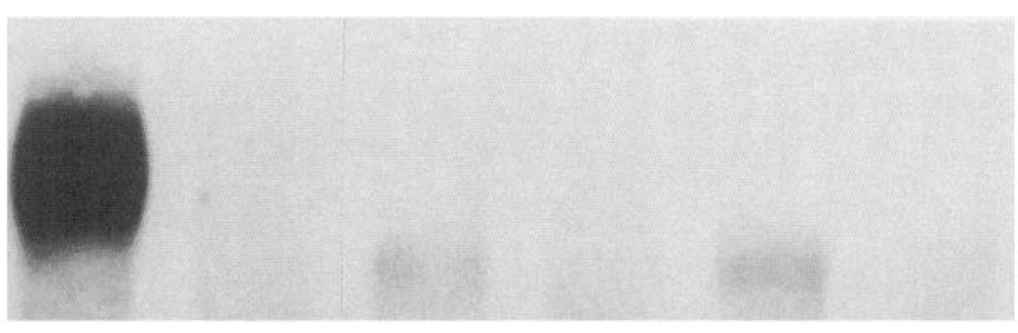

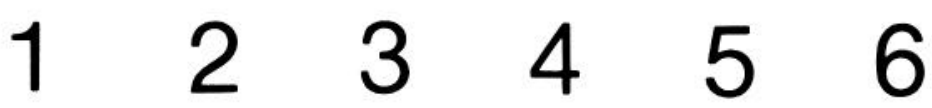

Figure 7. NGF stimulates tyrosine phosphorylation of trk. PC12 cells (lanes 1 and 2), dissociated cells from the rat septum (lanes 3 and 4 ), and dissociated cells from the ventral midbrain (containing the IPN, lanes 5 and 6 ) were treated with NGF (100 ng/ml) (lanes 1,3 , and 5$)$ or vehicle (lanes 2, 4, and 6) for $5 \mathrm{~min}$. Cells were then lysed, immunoprecipitated with an anti-pan-trk antibody (1088) followed by antigen blotting with an antibody to phosphotyrosine or RTA. NGF stimulated tyrosine phosphorylation of a $140 \mathrm{kDa}$ protein in PC12 cells. In both the septum and IPN, NGF stimulated tyrosine phosphorylation of a $125 \mathrm{kDa}$ protein. Bands of exactly the same molecular weight as seen with the phosphotyrosine antibody were seen on 1088 immunoprecipitates from PC12 cells or from these brain regions immunoblotted with the trkA specific antibody (RTA). In all lanes, equal amounts of total protein were immunoprecipitated $(2.25 \mathrm{mg})$. Thus, on a per mg/protein basis, the ventral midbrain (containing the IPN) appeared to contain more tyrosine phosphorylated trkA than the septum (containing the medial septal nucleus and vertical limb of the diagonal band).

express p75 $5^{\mathrm{NGFR}}$. NGF concentrations in the CNS are quite low ( $\sim 0.1-1 \mathrm{ng} / \mathrm{gm})$ (Longo et al., 1992); this would seem to require receptors that bind NGF with $\mathrm{Kd}$ values in the picomolar range. It is not yet clear whether trkA expression alone creates highaffinity binding (Hempstead et al., 1991), although there is evidence that this is the case (Jing, et al., 1992). Interestingly, NGF receptors in the IPN and in the striatum, whose neurons lack detectable p75 NGFR mRNA and protein (Gage et al., 1989; Springer et al., 1990; Holtzman et al., 1992b) demonstrate an affinity for NGF in the picomolar range (Richardson et al., 1986; Altar et al., 1991).

Although the function of the trkA expressing neurons described herein has not been defined, the role of these neurons is likely to be very different from that of forebrain cholinergic neurons expressing trkA. Two examples are the IPN and the area postrema. The IPN is thought of as part of the limbic system outflow into the brainstem (Nauta, 1958), with more recent evidence suggesting ascending influences as well (Vertes and Fass, 1988). There is also now data suggesting a role for the IPN in sleep, as disruption of the habenulo-interpeduncular pathway alters components of both REM and non-REM sleep in the rat (Haun et al., 1992). The area postrema has been suggested to be a major center for processing visceral sensory information, to elicit rapid homeostatic responses to fluid and nutrient imbalances (Contreras et al., 1984; Miselis et al., 1986a; Miselis et al., 1986b). One interesting feature links basal forebrain cholinergic neurons and one of the newly defined NGF-responsive regions. Many studies have shown that basal forebrain cholinergic neurons are particularly vulnerable in Alzheimer's disease (Coyle et al., 1983; Price, 1986; Vogels et al., 1990). While in general this is not the case for thalamic nuclei, the limbic nuclei in the thalamus, including the paraventricular and reuniens thalamic nuclei, are markedly affected and contain numerous neurofibrillary tangles (Braak and Braak, 1991). Our results suggest that if NGF is used in the treatment of Alzheimer's disease (Mobley, 1989), there might be improved function and protection not only of basal forebrain cholinergic neurons but also of vulnerable trkA containing neurons in the limbic thalamus.

\section{References}

Altar CA, Burton LE, Bennett GL, Dugich-Djordjevic M (1991) Recombinant human nerve growth factor is biologically active and labels novel high-affinity binding sites in rat brain. Proc Natl Acad Sci USA 88:281-285.

Barker PA, Lomen-Hoerth C, Gensch EM, Meakin SO, Glass DJ, Shooter EM (1993) Tissue-specific alternative splicing generates two isoforms of the trkA receptor. J Biol Chem 20:15150-15157.

Braak H, Braak E (1991) Alzheimer's disease affects limbic nuclei of the thalamus. Acta Neuropathol (Berl) 81:261-268.

Chao MV (1992) Neurotrophin receptors: a window into neuronal differentiation. Neuron 9:583-593.

Clary DO, Weskamp G, Austin LR, Reichardt LF (1994) TrkA crosslinking mimics neuronal responses to nerve growth factor. Mol Biol Cell, 5:549-563.

Contreras RJ, Kosten T, Bird E (1984) Area postrema: part of the autonomic circuitry of caloric homeostasis. Fed Proc 43:2966-2968.

Cordon-Cardo C, Tapley P, Jing S, Nanduri V, O'Rourke E, Lamballe F, Kovary K, Klein R, Jones KR, Reichardt LF, Barbacid M (1991) The trk tyrosine protein kinase mediates the mitogenic properties of nerve growth factor and neurotrophin-3. Cell 66:173-183.

Coyle JT, Price DL, DeLong MR (1983) Alzheimer's disease: a disorder of cortical cholinergic innervation. Science 219:1184-1190.

Cunningham ET, De Souza EB (1993) Localization of type I interleukin 1 receptor mRNA in brain and endocrine tissues by in situ hybridization histochemistry. In: Methods in neurosciences (De Souza EB, ed), pp 112-127. San Diego: Academic.

Davies AM, Lee KF, Jaenisch R (1993) p75-deficient trigeminal sensory neurons have an altered response to NGF but not other neurotrophins. Neuron 12:733-745.

Ferriero DM, Arcavi LJ, Sagar SM, McIntosh TK, Simon RP (1988) Selective sparing of NADPH-diaphorase neurons in neonatal hypoxia-ischemia. Ann Neurol 24:670-676.

Gage FH, Batchelor P, Chen KS, Chin D, Higgins GA, Koh S, Deputy S, Rosenberg MB, Fischer W, Bjorklund A (1989) NGF receptor reexpression and NGF-mediated cholinergic neuronal hypertrophy in the damaged adult neostriatum. Neuron 2:1177-1184.

Gnahn H, Hefti F, Heumann R, Schwab ME, Thoenen H (1983) NGFmediated increase of choline acetyltransferase (ChAT) in the neonatal rat forebrain: evidence for a physiological role of NGF in the brain. Dev Brain Res 9:42-52.

Groenewegen HJ, Ahlenius S, Haber SN, Kowall NW, Nauta WJH (1986) Cytoarchitecture, fiber connections and some histochemical aspects of the interpeduncular nucleus in the rat. J Comp Neurol 249: 69-102.

Hagg T, Hagg F, Vahlsing HL, Manthorpe M, Varon S (1989) Nerve 
growth factor effects on cholinergic neurons of neostriatum and nucleus accumbens in the adult rat. Neuroscience 30:95-103.

Hamill GS, Lenn NJ (1984) The subnuclear organization of the rat interpeduncular nucleus: a light and electron microscopic study. J Comp Neurol 222:396-408.

Haun F, Eckenrode TC, Murray M (1992) Habenula and thalamus cell transplants restore normal sleep behaviors disrupted by denervation of the interpeduncular nucleus. J Neurosci 12:3282-3290.

Hefti F, Hartikka F, Eckenstein F, Gnahn H, Heumann R, Schwab M (1985) Nerve growth factor increases choline acetyl-transferase but not survival or fiber outgrowth of cultured fetal septal cholinergic neurons. Neuroscience 14:55-68.

Hempstead BL, Martin Zanca D, Kaplan DR, Parada LF, Chao MV (1991) High-affinity NGF binding requires coexpression of the trk proto-oncogene and the low-affinity NGF receptor. Nature 350:678683.

Higgins GA, Koh S, Chen KS, Gage FH (1989) NGF induction of NGF receptor gene expression and cholinergic neuronal hypertrophy within the basal forebrain of the adult rat. Neuron 3:247-256.

Holtzman DM, Li Y, DeArmond SJ, McKinley MP, Gage FH, Epstein CJ, Mobley WC (1992a) A mouse model of neurodegeneration: atrophy of basal forebrain neurons in Ts 16 transplants. Proc Natl Acad Sci USA 89:1383-1387.

Holtzman DM, Li Y, Parada LF, Kinsman S, Chen CK, Valletta JS, Zhou J, Long J, Mobley WC (1992b) p140trk mRNA marks NGFresponsive forebrain neurons: evidence that $t r k$ gene expression is induced by NGF. Neuron 9:465-478.

Holtzman DM, Li Y, Chen K, Gage FH, Epstein CJ, Mobley WC (1993) Nerve growth factor reverses neuronal atrophy in a Down syndrome model of neurodegeneration. Neurology 43:2668-2673.

Jing S, Tapley P, Barbacid M (1992) Nerve growth factor mediates signal transduction through trk homodimer receptors. Neuron 9:1067-1079.

Johnson D, Lanahan A, Buck CR, Sehgal A, Morgan C, Mercer E, Bothwell M, Chan M (1986) Fxpression and structure of the human NGF receptor. Cell 47:545-554.

Johnson EM, Gorin PG (1980) Dorsal root ganglion neurons are destroyed by exposure in utero to maternal antibody to nerve growth factor. Science 210:916-918.

Johnston MV, Rutkowski JL, Wainer BH, Long JB, Mobley WC (1987) NGF effects on developing forebrain cholinergic neurons are regionally specific. Neurochem Res 12:985-994.

Kaplan DR, Hempstead BL, Martin-Zanca D, Chao MV, Parada LF (1991a) The trk proto-oncogene product: a signal transducing receptor for nerve growth factor. Science 252:554-558.

Kaplan DR, Martin-Zanca D, Parada LF (1991b) Tyrosine phosphorylation and tyrosine kinase activity of the trk proto-oncogene product induced by NGF. Nature 350:158-160.

Kasa P (1986) The cholinergic systems in the brain and spinal cord. Prog Neurobiol 26:211-227.

Klein R, Conway D, Parada LF, Barbacid M (1990) The trkB tyrosine kinase gene codes for a second neurogenic receptor that lacks the catalytic kinase domain. Cell 61:647-656.

Knusel B, Rabin S, Widmer HR, Hefti F, Kaplan DR (1992) Neurotrophin-induced trk receptor phosphorylation and cholinergic neuron response in primary cultures of embryonic rat brain neurons. Neuroreport 3:885-888

Knusel B, Rabin S, Hefti F, Kaplan DR (1994) Regulated neurotrophin receptor responsiveness during neuronal migration and early differentiation. J Neurosci 14:1542-1554

Koh S, Oyler G, Higgins GA (1989) Localization of nerve growth factor receptor messenger RNA and protein in the adult rat brain. Exp Neurol 106:209-221.

Lamballe F, Klein R, Barbacid M (1991) trkC, a new member of the trk family of tyrosine protein kinases, is a receptor for neurotrophin3. Cell 66:967-979.

Large TH, Bodary SC, Clegg DO, Weskamp G, Otten U, Reichardt LF (1986) Nerve growth factor gene expression in the developing rat brain. Science 234:352-355.

Lee K, Li E, Huber LJ, Landis SC, Sharpe AH, Chao MV, Jaenisch R (1992) Targeted mutation of the gene encoding the low affinity NGF receptor p75 leads to deficits in the peripheral sensory nervous system. Cell 69:737-749

Lenn NJ, Hamill GS (1984) Subdivisions of the interpeduncular nucleus: a proposed nomenclature. Brain Res Bull 13:203-204.
Lenn NJ, Leranth C, Zaborsky L (1985) Choline acetyltransferase immunoreactivity is localized to four synapses in the rat interpeduncular nucleus. J Neurocytol 14:909-919.

Levi-Montalcini R (1987) The nerve growth factor 35 years later. Science 237:1154-1161

Loeb DM, Maragos J, Martin-Zanca D, Chao MV, Parada LF, Greene LA (1991) The trk proto-oncogene rescues NGF responsiveness in mutant NGF-nonresponsive PC12 cell lines. Cell 66:961-966.

Longo FM, Holtzman DM, Grimes ML, Mobley WC (1992) Nerve growth factor: actions in the peripheral and central nervous systems. In: Neurotrophic factors (Fallon J, Loughlin S, eds), pp 209-256. New York: Academic.

Meakin SO, Shooter EM (1991) Tyrosine kinase activity coupled to the high-affinity nerve growth factor-receptor complex. Proc Natl Acad Sci USA 88:5862-5866.

Merlio J-P, Ernfors P, Jaber M, Persson H (1992) Molecular cloning of rat $t r k \mathrm{C}$ and distribution of cells expressing messenger RNAs for members of the trk family in the rat central nervous system. Neuroscience 51:513-532.

Middlemas DS, Lindberg RA, Hunter T (1991) trkB, a neural receptor protein-tyrosine kinase: evidence for a full-length and two truncated receptors. Mol Cell Biol 11:143-153.

Miselis RR, Shapiro RE, Hyde TM (1986a) The area postrema. In: Circumventricular organs and body fluids (Gross PM, ed), pp 185207. Boca Raton, FL: CRC

Miselis RR, Shapiro RE, Hyde TM (1986b) Area postrema and adjacent solitary nucleus in water and energy balance. Fed Proc 43:29692971.

Mobley WC (1989) Nerve growth factor in Alzheimer's disease: to treat or not to treat? Neurobiol Aging 10:578-580.

Mobley WC, Rutkowski JL, Tennekoon SJ, Buchanan K, Johnston MV (1985) Choline acetyltransferase in striatum of neonatal rats in creased by nerve growth factor. Science 229:284-287.

Mobley WC, Rutkowski JL, Tennekoon GI, Gemski J, Buchanan K, Johnston MV (1986) Nerve growth factor increases choline acetyltransferase activity in developing basal forebrain neurons. Mol Brain Res 387:53-62.

Nauta WJH (1958) Hippocampal projections and related neural pathways to the midbrain in the cat. Brain 81:319-341.

Palkovits M, Saavedra JM, Kobayashi RM, Brownstein M (1974) Choline acetyltransferase content of limbic nuclei of the rat. Brain Res 79:443-450.

Paxinos G, Watson C (1986) The rat brain in stereotaxic coordinates Marrickville, Australia: Academic.

Price DL (1986) New perspectives on Alzheimer's disease. Annu Rev Neurosci 9:489-512.

Radeke MJ, Misko TP, Hsu C, Herzenberg LA, Shooter EM (1987) Gene transfer and molecular cloning of the rat nerve growth factor receptor. Nature 325:593-597.

Raivich G, Kretuzber GW (1987) The localization and distribution of high affinity $\beta$-nerve growth factor binding sites in the central nervous system of the adult rat. A light microscopic autoradiographic study using [125I] $\beta$-nerve growth factor. Neuroscience 20:22-36.

Richardson PM, Verge-Issa VMK, Riopcllc RJ (1986) Distribution of neuronal receptors for nerve growth factor in the rat. $J$ Neurosci 6:2312-2321.

Springer JE, Robbins E, Meyer S, Baldino FJ, Lewis ME (1990) Localization of nerve growth factor receptor mRNA in the rat basal forebrain with in situ hybridization histochemistry. Cell Mol Neurobiol 10:33-39.

Steininger TL, Wainer BH, Klein R, Barbacid M, Palfrey HC (1993) High-affinity nerve growth factor receptor (Trk) immunoreactivity is localized in cholinergic neurons of the basal forebrain and striatum in the adult rat brain. Brain Res 612:330-335.

Thoenen II (1991) The changing scene of neurotrophic factors. Trends Neurosci 14:165-170.

Tsoulfas P, Soppet D, Escandon E, Tessarollo L, Mendoza-Ramirez J-L, Rosenthal A, Nikolics K, Parada LF (1993) The rat trkC locus encodes multiple neurogenic receptors that exhibit differential response to neurotrophin-3 in PC12. Neuron 10:975-990.

Valenzuela DM, Maisonpierre PC, Glass DJ, Rojas E, Nunez L, Kong Y, Gies DR, Stitt TN, Ip NY, Yancopoulos GD (1993) Alternative forms of rat trkC with different functional capabilities. Neuron 10: 963-974. 
Venero JL, Hefti F (1993) TrkA NGF receptor expression by noncholinergic thalamic neurons. Neuroreport 4:959-962.

Verdi JM, Birren SJ, Ibanez CF, Persson H, Kaplan DR, Benedetti M,

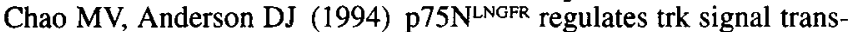
duction and NGF-induced neuronal differentiation in MAH cells. Neuron 12:733-745.

Vertes RP, Fass B (1988) Projection between the interpeduncular nucleus and basal forebrain in the rat as demonstrated by the anterograde and retrograde transport of WGA-HRP. Exp Brain Res 73:23-31.

Vogels OJM, Broere AJ, Ter Laak HJ, Ten Donkelaar HJ, Nieuwenhuys
R, Schulte BPM (1990) Cell loss and shrinkage in the nucleus basalis of Meynert complex in Alzheimer's disease. Neurobiol Aging 11: $3-13$.

Whittemore SR, Ebendal T, Larkfors L, Olson L, Seiger A, Stromberg I, Persson H (1986) Developmental and regional expression of betanerve growth factor messenger RNA and protein in the rat central nervous system. Proc Natl Acad Sci USA 83:817-821.

Zhou J, Holtzman DM, Weiner R, Mobley WC (1994) TrkA confers neuronal-like NGF response to immortalized hypothalamic neurons. Proc Natl Acad Sci USA 91:3824-3828. 